\title{
BIOGEOGRAPHY OF BACTERIOPLANKTON IN LAKES AND STREAMS OF AN ARCTIC TUNDRA CATCHMENT
}

\author{
Byron C. Crump, ${ }^{1,4}$ Heather E. Adams, ${ }^{2}$ John E. Hobbie, ${ }^{3}$ and George W. Kling ${ }^{2}$ \\ ${ }^{1}$ University of Maryland Center for Environmental Science, Horn Point Laboratory, Cambridge, Maryland 21613 USA \\ ${ }^{2}$ University of Michigan, Ann Arbor, Michigan 48109 USA \\ ${ }^{3}$ The Ecosystems Center, Marine Biological Laboratory, Woods Hole, Massachusetts 02543 USA
}

\begin{abstract}
Bacterioplankton community composition was compared across 10 lakes and 14 streams within the catchment of Toolik Lake, a tundra lake in Arctic Alaska, during seven surveys conducted over three years using denaturing gradient gel electrophoresis (DGGE) of PCR-amplified rDNA. Bacterioplankton communities in streams draining tundra were very different than those in streams draining lakes. Communities in streams draining lakes were similar to communities in lakes. In a connected series of lakes and streams, the stream communities changed with distance from the upstream lake and with changes in water chemistry, suggesting inoculation and dilution with bacteria from soil waters or hyporheic zones. In the same system, lakes shared similar bacterioplankton communities (78\% similar) that shifted gradually down the catchment. In contrast, unconnected lakes contained somewhat different communities (67\% similar). We found evidence that dispersal influences bacterioplankton communities via advection and dilution (mass effects) in streams, and via inoculation and subsequent growth in lakes. The spatial pattern of bacterioplankton community composition was strongly influenced by interactions among soil water, stream, and lake environments. Our results reveal large differences in lake-specific and stream-specific bacterial community composition over restricted spatial scales $(<10 \mathrm{~km})$ and suggest that geographic distance and connectivity influence the distribution of bacterioplankton communities across a landscape.
\end{abstract}

Key words: Arctic; bacteria; bacterial production; bacterioplankton; biogeography; diversity; denaturing gradient gel electrophoresis; DGGE; metacommunity.

\section{INTRODUCTION}

Freshwater ecosystems are networks of distinct lake, stream, soil water, and groundwater environments that are linked within catchments by downslope water flow. Limnologists incorporate the role of catchments in lake and stream studies, but in the last decade this approach has expanded to include hydrological networks and concepts in landscape ecology. The spatial arrangement of lakes and streams on the landscape can predict various chemical and biological characteristics (Magnuson et al. 1990, Soranno et al. 1999, Riera et al. 2000) and in part the interactions among aquatic habitats control their individual functioning (Kling et al. 2000). Spatial controls have long been central to the study of metapopulations (Levins 1969, Hanski and Gilpin 1991) and more recently metacommunities (Leibold et al. 2004), but most studies of bacterial community composition have focused only on single environment types such as lakes or streams. Comparisons across environments are less common (e.g., Dolan 2005) and interactions among organisms populating these environments

Manuscript received 6 March 2006; revised 12 July 2006; accepted 17 July 2006. Corresponding Editor: R. B. Jackson. For reprints of this Special Feature, see footnote 1, p. 1343.

${ }^{4}$ E-mail: bcrump@hpl.umces.edu are rarely investigated (e.g., Crump et al. 2004). To gain a better understanding of bacterial community composition across a landscape, we analyzed bacterioplankton (i.e., bacteria suspended in water) in lakes and streams of an arctic catchment in order to describe how spatial patterns in diversity are related to geographic position, water flow, habitat connectivity, and physical and chemical variability of these waters.

Variations in bacterioplankton community composition, characterized with PCR-based community fingerprinting techniques, often correlate with physical, chemical, and biological factors (Muylaert et al. 2002, Simek et al. 2002, Yannarell and Triplett 2004). Recently, a few studies indirectly looked at dispersal of bacterioplankton by including the spatial distribution of habitats as an independent variable. They found that bacterioplankton communities were more similar in lakes that were closer together than in lakes farther apart (Reche et al. 2005), that communities in two adjacent but non-intersecting river systems were nearly identical (Crump and Hobbie 2005), and that communities in lakes from the same catchment were more similar than in lakes across catchments, including isolated lakes in which these similarities could not be caused by water transport of bacterial cells (Lindström and Bergström 2005). In contrast to these studies, one study showed that the distribution of lake bacterial 
communities was unrelated to geographic location and not influenced by stream flow between lakes (Konopka et al. 1999). Although studies on this topic are still few, it is probable that a gradient of potential controls on community composition exists, with one endpoint governed by high dispersal rates leading to similar local communities in nearby sites and the opposite endpoint governed by various edaphic or environmental conditions such as DOM chemistry at local sites which select for particular community members. This latter control has been demonstrated experimentally, where variations in DOM composition led to changes in aquatic bacterial community structure (Findlay et al. 2003, Judd 2004, Judd et al. 2006).

In the context of metacommunity dynamics, interactions among communities in specific habitats can be set by mass dispersal effects, followed by species sorting. For aquatic bacteria, the mass effect is dominated by advection of large numbers of cells by rivers or during storm events, but can also include the process of crossinoculation of small numbers of cells (e.g., via small streams or wind) between habitats. For example, advection of bacterial cells into lakes from land via streams can be very high (Bergström and Jansson 2000), and in some cases can exceed in situ rates of bacterial cell production. Such advection can also influence community composition in lakes (Crump et al. 2003, Lindström and Bergström 2004) and estuaries (Crump et al. 1999, 2004), and is most important in systems with short water residence times (Lindström et al. 2005), which increase the probability of a strong mass effect.

By comparison, when small numbers of cells are transferred between habitats their influence on bacterial community composition is less clear. Upstream environments are metacommunities for downstream habitats, and these metacommunities are theoretically enormous (Finlay 2002, Fenchel 2003) because bacteria are extremely abundant and fast growing. Thus the probability of their dispersal is very high and the probability of extinction low; this leads to the longstanding hypothesis that "everything is everywhere, but the environment selects" (Baas-Becking 1934). Certainly this hypothesis is limited in the literal sense because severe environments can eliminate even bacterial resting stages, and recent studies also challenge this hypothesis by identifying geographic isolation in some microbial taxa (Hollibaugh et al. 2002, Papke et al. 2003, Whitaker et al. 2003). However, widespread functional redundancy among bacteria makes it difficult to predict which organisms from a metacommunity will become abundant in any particular environment (Curtis and Sloan 2004).

Therefore, the data currently available suggest that bacterial community composition in freshwaters is controlled by dispersal (biogeography) or environment (habitat quality), or both, and that these controls operate across a spatial range from local to regional. Our goals here are to (1) describe the spatial patterns of bacterioplankton community composition in a complex catchment with both connected and isolated lakes and streams, (2) determine whether environmental factors predict community composition, and (3) investigate the mechanisms and potential influence of dispersal by downslope water flow on patterns of community composition.

\section{Methods}

Toolik Lake $\left(1.5 \mathrm{~km}^{2}\right)$ is located on the North Slope of Alaska $\left(68^{\circ} 38^{\prime} 00^{\prime \prime} \mathrm{N}, 149^{\circ} 36^{\prime} 15^{\prime \prime} \mathrm{W}\right)$ about $180 \mathrm{~km}$ south of the Arctic Ocean (see Plate 1). The Toolik Lake catchment (6690 ha) is a research site for the Arctic Long-Term Ecological Research program, and is an archetype of regional tundra terrain (Fig. 1). The main inlet stream to Toolik Lake drains $75 \%$ of the catchment and is formed by the merger of two streams, each draining large catchments similar in area but with different lake-stream configurations (Fig. 1). One contains a chain of nine lakes while the other contains only one lake near its base fed by a large network of headwater streams (Table 1). Stream flow begins in May and quickly reaches peak flow from snowmelt runoff (Hobbie et al. 1983). The lakes usually become ice-free and thermally stratified by late June, and remain that way until early October when ice forms.

The length of streams in the Toolik catchments varies (Fig. 1). Connecting streams flow between lakes, and, at least initially, contain lake water and lake bacteria. Lake-less streams are those that have no upstream lakes and thus contain water and bacteria from the upland tundra and stream habitats. Lakes and streams were sampled once in 2000 (6-7 July), three times in 2001 (2930 June, 17-18 July, 7-8 August), and three times in 2002 (25-26 June, 16-17 July, 6-8 August). Samples were collected from the lake middle at a depth of $1 \mathrm{~m}$, from inlet streams just upstream of lakes, and from two other streams (I-8 headwaters and Milky Way). Outlet streams of each lake were also sampled for physical and chemical measurements. Note that inlet streams to Lakes I-4 and I-7 are very short and were not sampled. Also, "Lake" I-9 was not sampled because it is a small mixing pool for two streams.

Lake sampling included samples for dissolved organic carbon (DOC) as well as depth profiles of temperature, $\mathrm{pH}$, specific conductivity $(\mu \mathrm{S} / \mathrm{cm})$, and dissolved oxygen (mg/L) measured with a Hydrolab SVR3-DL Surveyor 3 H20-BT multiprobe (Hach Company, Loveland, Colorado, USA). Streams (at lake inlets and lake outlets) were sampled for temperature, specific conductivity, $\mathrm{pH}$, $\mathrm{CO}_{2}, \mathrm{CH}_{4}, \mathrm{DOC}, \mathrm{PO}_{4}{ }^{3-}, \mathrm{Ca}^{2+}, \mathrm{Mg}^{2+}, \mathrm{Na}^{+}, \mathrm{Cl}^{-}$, and $\mathrm{Si}$. Variables beginning with DOC in the previous list were measured in samples filtered in the field through Whatman GF/F filters (nominal pore size $0.6 \mu \mathrm{m}$ ) and analyzed within 24 hours $\left(\mathrm{PO}_{4}{ }^{3-}\right)$, kept cold and dark until analysis $\left(\mathrm{Cl}^{-}\right)$, or preserved with acid in the field and kept cold and dark until analysis. All other methods 
A
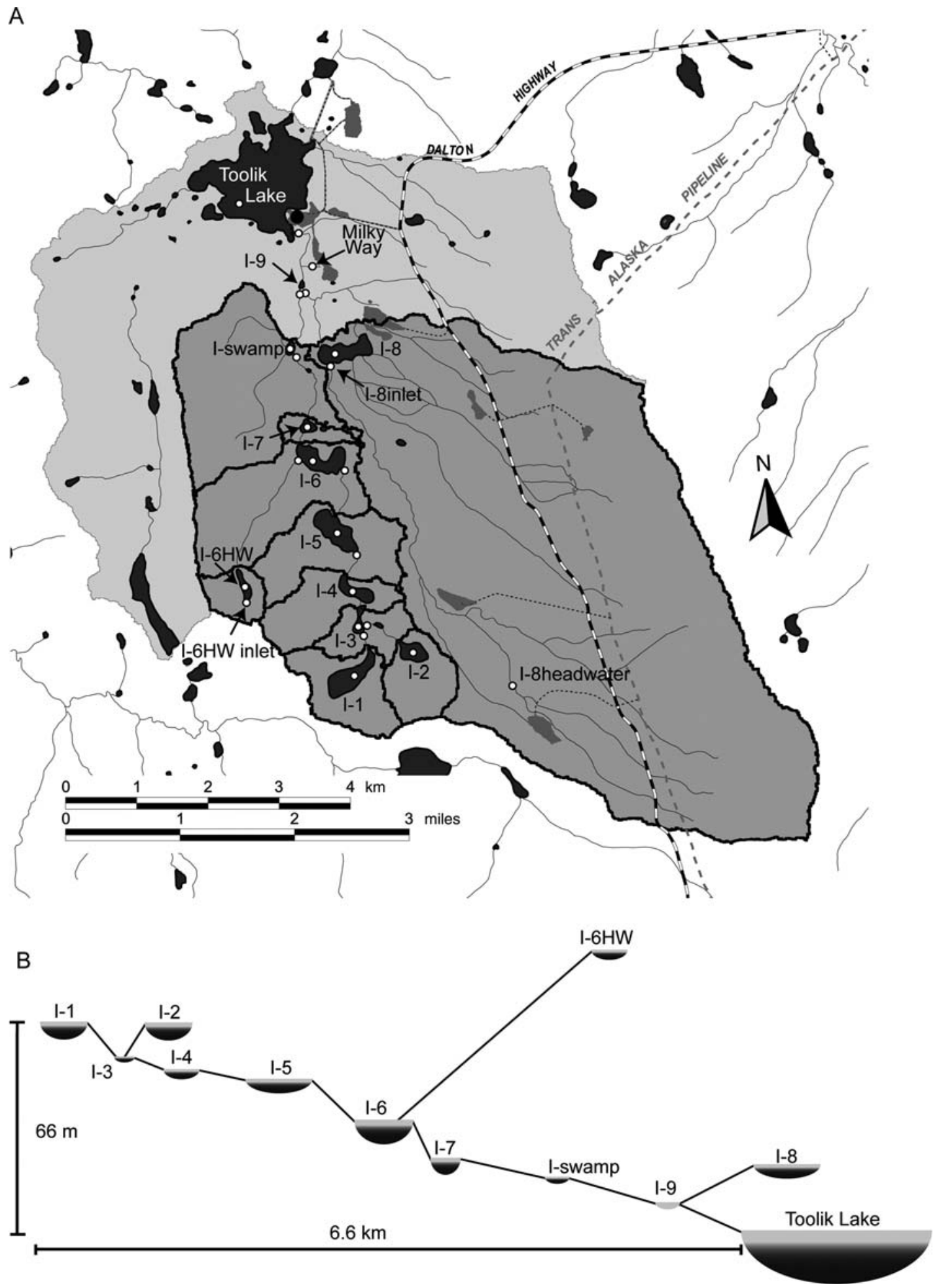

FIG. 1. (A) Map of Toolik Lake watershed (arctic Alaska) with catchments indicated for each upstream lake. Sampling sites are indicated with open circles. Names are provided for lakes and lake-less streams. Connecting streams were sampled at the inlets to lakes and were named according to source lake and receiving lake (names provided in Table 1 and in Kling et al. [2000]). (B) Diagram of lakes scaled to elevation and maximum depth. 
TABLE 1. Names and descriptions of lakes and streams sampled for this study, and estimates of water residence times (for epilimnia and whole streams) and bacterial community doubling times in lake epilimnia and streams.

\begin{tabular}{|c|c|c|c|c|c|}
\hline Lake, stream & $\begin{array}{l}\text { Lake hydrology/ } \\
\text { order, stream category }\end{array}$ & $\begin{array}{l}\text { Elevation } \\
(\mathrm{m} \text { a.s.l. }) \dagger\end{array}$ & $\begin{array}{l}\text { Catchment } \\
\text { area (ha) }\end{array}$ & $\begin{array}{l}\text { Range of residence } \\
\text { times (d) }\end{array}$ & $\begin{array}{c}\text { Range of } \\
\text { bacteria community } \\
\text { doubling times (d) }\end{array}$ \\
\hline I-1 & $\mathrm{H} / 0$ & 785 & 105.7 & $933-1539$ & $0.9-11$ \\
\hline $\mathrm{I}-2$ & $\mathrm{H} / 0$ & 785 & 135.3 & $346-1035$ & $1.0-59$ \\
\hline I-3 & $\mathrm{F} / 2$ & 774 & 95.3 & $77-131$ & $0.1-13$ \\
\hline $\mathrm{I}-4$ & $\mathrm{~F} / 2$ & 770 & 94.2 & $195-546$ & $0.2-3.5$ \\
\hline I-5 & $\mathrm{F} / 2$ & 767 & 185.7 & $483-813$ & $0.6-9.3$ \\
\hline I-6HW & $\mathrm{H} / 0$ & 808 & 52 & $160-265$ & $1.8-22$ \\
\hline I-6 & $\mathrm{F} / 2$ & 754 & 273 & $235-580$ & $1.7-38$ \\
\hline I-7 & $\mathrm{F} / 2$ & 742 & 56.1 & $141-367$ & $1.0-7.6$ \\
\hline I-swamp & $\mathrm{F} / 2$ & 736 & $302.6 \S$ & $39-106$ & $0.7-7.8$ \\
\hline $\mathrm{I}-8$ & $\mathrm{IH} / 2$ & 744 & 2928.5 & 26-28 & $0.6-9.7$ \\
\hline I- 1 to $\mathrm{I}-3$ inlet & connecting stream & 774 & 4.6 & $0.01-0.75$ & $1.7-20$ \\
\hline I- 2 to I-3 inlet & connecting stream & 774 & 31.2 & $0.02-0.25$ & $0.4-13$ \\
\hline I-3 to I-4 inlet & connecting stream & 770 & 2.3 & $0.02-0.06$ & na \\
\hline I- 4 to $\mathrm{I}-5$ inlet & connecting stream & 767 & 22.9 & $0.03-0.50$ & $1.1-15$ \\
\hline I- 5 to I- 6 inlet & connecting stream & 754 & 30.6 & $0.02-1.13$ & $1.0-8.0$ \\
\hline I-6HW inlet & lake-less stream & 808 & 13.8 & $0.03-0.19$ & $25-31$ \\
\hline I-6HW to I-6 inlet & connecting stream & 754 & 163.7 & $\sim 0.08-2.71$ & $4.7-54$ \\
\hline I-6 to I-7 inlet & connecting stream & 742 & 4.0 & $0.01-0.01$ & na \\
\hline I-7 to I-swamp inlet & connecting stream & 736 & 46.4 & $0.05-6.67$ & $2.5-7.6$ \\
\hline I-swamp to I-9 & connecting stream & 728 & 29.7 & $0.02-0.50$ & $1.7-9.9$ \\
\hline I-8 headwaters & lake-less stream & 808 & 986.5 & na & $3.5-36$ \\
\hline I-8 inlet & lake-less stream & 744 & $485.3 t$ & $0.27-4.2$ & $2.6-24$ \\
\hline I-8 to I-9 & connecting stream & 728 & $168.5^{\circ}$ & $0.02-0.33$ & $1.2-13$ \\
\hline Milky Way & lake-less stream & 725 & 7.4 & $0.01-1.08$ & $3.3-6.9$ \\
\hline
\end{tabular}

Note: Abbreviations are: $\mathrm{H}$, headwater; F, flow-through; IH, inflow headwater; na, not available.

$\uparrow$ Above sea level.

\$ Excludes drainage area of I-8 headwaters.

$\S$ I-swamp catchment area updated from Kling et al. (2000).

of collection, processing, and analysis are detailed in Kling et al. (2000).

Epilimnion water residence time was estimated by multiplying whole-lake residence times (Kling et al. $2000)$ by the volumetric fraction contained in the epilimnion (Table 1). Epilimnion volume was calculated using the mean pycnocline depth (based on profiles of temperature and conductivity) for the summer season and the depth-volume relationship of each lake. In cases where the depth-volume relationship was unknown (Iswamp, I-6HW), epilimnion volume was calculated as the frustum of an inverted cone with volume and surface area equal to that of each lake with the lower frustum level taken as pycnocline depth.

Stream water residence times were calculated using discharge data collected in summer 2005 from all streams, sampled continuously for I-8 inlet, I-8 to I-9, and I-7 to I-9, and three times per summer for all other streams. The average residence time of stream water was calculated as the length of stream in meters divided by the mean, volume-weighted water velocity in meters per second.

Bacterial production was determined in the field by measuring the incorporation of ${ }^{14} \mathrm{C}$-labeled $l$-leucine (30 $\mathrm{nmol} / \mathrm{L}$ final concentration) into the cold trichloroacetic acid (TCA) insoluble fraction of macromolecules in two subsamples incubated for 2-4 hours at in situ temperatures in the dark (because we have no separate measure of Archaeal abundance, this determination is more specifically the prokaryotic production). Incubations were conducted in sterile plastic $20-\mathrm{mL}$ scintillation vials packed in stainless steel thermoses containing freshly collected sample water. Vials were capped with sterile Teflon-silicone septa so that incubations could be ended via syringe injection of a 50/50 mass/volume solution of TCA (5\% final concentration). Procedures for extracting TCA-insoluble macromolecules are described elsewhere (Crump et al. 2003). Bacterial carbon production (BP) was calculated from leucine incorporation following Kirchman (1993).

Doubling times of bacterial communities were calculated from bacterial production (BP) and bacterial biomass (BB). BB was assumed to be $20 \mu \mathrm{g} \mathrm{C} / \mathrm{L}$, which was calculated from typical cell concentrations in these systems $\left(1 \times 10^{9}\right.$ cells/L [Hobbie et al. 1983, Crump et al. 2003]) and an experimentally determined conversion factor (20 fg C/cell [Lee and Fuhrman 1987]). Doubling time is DT $=(\ln 2) / \mu$, where $\mu=(\mathrm{BP} / \mathrm{BB})(\mathrm{Kirchman}$ 2002). These doubling times are averages for all bacterial cells and populations in each community regardless of relative activity.

Water samples were collected in clean, sample-rinsed opaque plastic bottles filled by hand (streams) or from a Van Dorn sampler (lakes), and were immediately processed for DNA samples. Samples were kept on ice during the sampling day, and subsequently stored at $-80^{\circ} \mathrm{C}$ until processed. DNA sampling and extraction procedures were previously described (Crump et al. 
TABLE 2. Results of canonical correspondence analysis (CCA) using forward-selection criteria.

\begin{tabular}{|c|c|c|c|c|c|}
\hline Date & Samples & Model $\dagger$ & $\Sigma \lambda_{\text {canonical }} \neq$ & $\Sigma \lambda_{i} \S$ & $\begin{array}{l}\text { Variance of DGGE } \\
\text { explained }(\%) \|\end{array}$ \\
\hline July 2000 & lakes and streams & temperature, conductivity & 0.52 & 1.30 & 40 \\
\hline June 2001 & lakes and streams & conductivity, DOC & 0.40 & 1.76 & 23 \\
\hline July 2001 & lakes and streams & elevation, temperature & 0.48 & 1.98 & 24 \\
\hline August 2001 & lakes and streams & elevation, temperature & 0.60 & 2.00 & 30 \\
\hline June 2002 & lakes and streams & elevation, temperature, conductivity & 0.67 & 2.10 & 32 \\
\hline July 2002 & lakes and streams & elevation, temperature, $\mathrm{pH}$ & 0.52 & 1.40 & 37 \\
\hline August 2002 & lakes and streams & temperature & 0.20 & 1.58 & 13 \\
\hline July 2000 & lakes & conductivity, $\mathrm{pH}$ & 0.26 & 0.62 & 42 \\
\hline June 2001 & lakes & ns & 0.00 & 0.89 & 0 \\
\hline July 2001 & lakes & elevation & 0.22 & 1.38 & 16 \\
\hline August 2001 & lakes & $\begin{array}{l}\text { elevation, temperature, conductivity, } \\
\text { headwater lakes }\end{array}$ & 0.64 & 0.89 & 71 \\
\hline June 2002 & lakes & elevation, headwater lakes & 0.37 & 1.13 & 33 \\
\hline July 2002 & lakes & elevation, conductivity, lake hydrology & 0.52 & 0.77 & 68 \\
\hline August 2002 & lakes & lake hydrology & 0.31 & 0.72 & 43 \\
\hline
\end{tabular}

Note: ns, not significant.

$\uparrow$ Environmental variables tested were elevation, temperature, conductivity, $\mathrm{pH}$, and DOC (dissolved organic carbon). For lakeonly analyses, lake hydrology categories were included as logical (true/false) variables (see Table 1). Inclusion of "lake hydrology" in the model indicates that all three categories were significant.

$\$ \Sigma \lambda_{\text {canonical }}$ is the sum of eigenvalues associated with selected environmental variables.

$\S \Sigma \lambda_{i}$ indicates sum of eigenvalues.

\| The eigenvalue ratio $\Sigma \lambda_{\text {canonical }} / \Sigma \lambda_{i}=$ variance in DGGE explained by environmental variables.

2003). Denaturing gradient gel electrophoresis (DGGE) procedures and methods of analysis followed Muyzer et al. (1993) and were described in detail elsewhere (Crump and Hobbie 2005).

All variables for statistical tests were transformed to correct for deviations from normality and homoscedasticity. Transformations were unsuccessful for stream variables conductivity, $\mathrm{PO}_{4}{ }^{3-}, \mathrm{Ca}^{2+}, \mathrm{Mg}^{2+}$, and $\mathrm{Cl}^{-}$, meaning that the stepwise regression models using $P$ values for these variables may be biased. Variability in environmental factors among streams and lakes were identified using one-way ANOVA with Bonferroni corrections for multiple comparisons. For each sampling date, canonical correspondence analysis (CCA, CANOCO 4.5; Microcomputer Power, Ithaca, New York, USA) was applied to determine the extent to which environmental variables explained patterns of similarity in community composition across the landscape (see Table 2). The CCA analyses used elevation, temperature, conductivity, $\mathrm{pH}$, and DOC as explanatory variables, and for lakes one qualitative variable was coded as three binary dummy variables based on lake hydrology (headwater, inflow headwater, and flowthrough). Variables were added by forward selection until model improvement failed $(P<0.05)$.

Stepwise multiple regression was used to characterize spatial patterns across all sampling dates using DGGE similarity values as dependent variables; comparisons were made within and not between sampling dates in order to focus on spatial patterns in community composition. To investigate the potential causes of community change along stream lengths, DGGE similarity values between every connecting stream and its source lake were used as dependent variables and environmental measurements as independent variables, including calculated changes in chemistry between lake inlets and lake outlets (downstream inlet minus upstream outlet; see Table 3). The chemistry of outlet stream samples was always very similar to epilimnetic lake samples in temperature, conductivity and $\mathrm{pH}$, as found previously (Kling et al. 2000). Difference data were shifted to positive non-zero numbers prior to transformation by subtracting the most negative value and adding one. To investigate the potential causes of community variability among lakes, a similar regression analysis was done using geographic distance and pairwise differences in environmental measurements as independent variables.

\section{RESUlts}

Flow rate of the Toolik inlet stream represents well the relative stream flow rates throughout the catchment. Daily mean flow of Toolik inlet stream during sampling was $1.00 \mathrm{~m}^{3} / \mathrm{s}$, similar to a mean of $1.34 \mathrm{~m}^{3} / \mathrm{s}$ for the entire ice-free seasons of 2000 to 2002. Rain storms causing small spikes in stream flow occurred one to two days prior to sampling campaigns on 6-7 July 2000 and 29-30 June 2001, raising daily mean flow rates to 1.65 $\mathrm{m}^{3} / \mathrm{s}$ and $1.71 \mathrm{~m}^{3} / \mathrm{s}$, respectively. Inlet stream flow was exceptionally low $\left(<0.01 \mathrm{~m}^{3} / \mathrm{s}\right)$ during sampling from 6 7 August 2002.

One-way ANOVAs of environmental factors identified significant variability among lakes for conductivity and DOC, and among streams for all variables except DOC and $\mathrm{PO}_{4}{ }^{3-}$. Lake I-8 had elevated conductivity relative to Lakes I-1 through I-5 $(P<0.001)$, but was not significantly different from lakes I-6, I-7, or Iswamp. Lake-less streams and the very long stream I$6 \mathrm{HW}$ to I-6 were elevated in conductivity, $\mathrm{Ca}^{2+}, \mathrm{Mg}^{2+}$, 
TABle 3. Results of stepwise multiple regressions (entry $P<0.05$, removal $P<0.10$ ).

\begin{tabular}{|c|c|c|c|c|c|c|c|c|}
\hline \multirow[b]{2}{*}{ Data set } & \multirow[b]{2}{*}{ Model $\uparrow, \uparrow$} & \multirow[b]{2}{*}{$r^{2}$} & \multirow[b]{2}{*}{$n$} & \multirow[b]{2}{*}{$P$} & \multicolumn{4}{|c|}{ Beta weight§ } \\
\hline & & & & & 1 & 2 & 3 & 4 \\
\hline Streams, all dates & $\mathrm{K}^{+}$, stream length, inlet flow rate & 0.76 & 45 & $<0.0001$ & 0.57 & -0.44 & 0.32 & \\
\hline Streams, no August 2002 & $\mathrm{Mg}^{2+}$, stream length, $\mathrm{CO}_{2}$ & 0.87 & 38 & $<0.0001$ & 0.59 & -0.36 & -0.32 & \\
\hline $\begin{array}{l}\text { Streams, all dates, } \\
\text { no I-6HW to I-6 }\end{array}$ & $\mathrm{CO}_{2}$, drainage area & 0.47 & 39 & $<0.0001$ & -0.74 & -0.31 & & \\
\hline $\begin{array}{l}\text { Streams, no August 2002, } \\
\text { no I-6HW to I-6 }\end{array}$ & $\mathrm{CO}_{2}$, temperature & 0.42 & 33 & $<0.0001$ & -0.64 & -0.45 & & \\
\hline Lakes, all lakes & $\begin{array}{l}\text { distance, conductivity, temperature, } \\
\text { DOC }\end{array}$ & 0.22 & 297 & $<0.0001$ & -0.34 & -0.33 & -0.19 & -0.14 \\
\hline Lakes, HW to $\mathrm{HW} \|$ & distance & 0.36 & 39 & $<0.0001$ & -0.60 & & & \\
\hline Lakes, chain to chain & distance, elevation, DOC, $\mathrm{pH}$ & 0.36 & 100 & $<0.0001$ & -0.98 & 0.54 & -0.19 & -0.19 \\
\hline Lakes, HW to chain & $\mathrm{pH}$ & 0.05 & 158 & 0.005 & -0.22 & & & \\
\hline Lakes, July 2000 & conductivity, DOC & 0.32 & 36 & 0.002 & -0.52 & -0.34 & & \\
\hline Lakes, June 2001 & DOC, distance & 0.41 & 45 & $<0.0001$ & -0.46 & -0.38 & & \\
\hline Lakes, July 2001 & conductivity & 0.20 & 45 & 0.048 & -0.30 & & & \\
\hline Lakes, August 2001 & temperature, elevation, conductivity & 0.47 & 45 & $<0.0001$ & -0.40 & -0.36 & -0.28 & \\
\hline Lakes, June 2002 & elevation & 0.10 & 45 & 0.039 & -0.31 & & & \\
\hline Lakes, July 2002 & conductivity, distance & 0.50 & 36 & $<0.0001$ & -0.51 & -0.30 & & \\
\hline Lakes, August 2002 & distance & 0.18 & 36 & 0.011 & -0.42 & & & \\
\hline
\end{tabular}

Notes: For streams, DGGE similarity values between lakes and inlets to the next downstream lake served as the dependent variable. For lakes, DGGE similarity values between lakes served as the dependent variable.

$\dagger$ Independent variables for streams: stream length $(\mathrm{km})$, stream drainage area (ha), mean daily Toolik Inlet stream flow rate, and the change along the streams (downstream lake inlet minus upstream lake outlet) in temperature $\left({ }^{\circ} \mathrm{C}\right)$, conductivity $(\mu \mathrm{S} / \mathrm{cm})$, $\mathrm{pH}, \mathrm{CH}_{4}(\mu \mathrm{mol} / \mathrm{L}), \mathrm{CO}_{2}(\mu \mathrm{mol} / \mathrm{L}), \mathrm{PO}_{4}{ }^{3-}(\mu \mathrm{mol} / \mathrm{L}), \mathrm{Ca}^{2+}(\mathrm{mg} / \mathrm{L}), \mathrm{Mg}^{2+}(\mathrm{mg} / \mathrm{L}), \mathrm{Na}^{+}(\mathrm{mg} / \mathrm{L}), \mathrm{K}^{+}(\mathrm{mg} / \mathrm{L}), \mathrm{Cl}^{-}(\mu \mathrm{mol} / \mathrm{L})$, and Si $(\mu \mathrm{mol} / \mathrm{L})$.

\$ Independent variables for lakes: distance between lakes $(\mathrm{km})$ and the absolute value of the difference between lakes in elevation $(\mathrm{m})$, temperature $\left({ }^{\circ} \mathrm{C}\right)$, conductivity $(\mu \mathrm{S} / \mathrm{cm}), \mathrm{pH}$, dissolved oxygen $(\mu \mathrm{mol} / \mathrm{L})$, and DOC $(\mu \mathrm{mol} / \mathrm{L})$.

$\S$ Beta weights are standardized coefficients that indicate the relative importance of variables to the regression model.

|| HW indicates Lakes I-1, I-2, I-6HW, and I-8.

- Chain indicates Lakes I-3, I-4, I-5, I-6, I-7, and I-swamp.

$\mathrm{Na}^{+}$, and $\mathrm{Si}$, and depleted in $\mathrm{K}^{+}$and $\mathrm{Cl}^{-}$relative to other streams.

Hydraulic retention times of lake epilimnia were variable, although most were longer than the entire ice-free season (Table 1). Bacterial community doubling time was much shorter than epilimnion water residence times (Table 1), implying that under low or mean flow conditions the advection of bacterial cells via inlet streams and groundwater is minor compared to autochthonous production of new cells. In contrast, average water residence times in streams were shorter than bacterial doubling times, especially during high flow (Table 1), implying that streams act as conduits of communities and not as reactors producing new communities through growth of populations betteradapted to local environmental conditions.

The number of DGGE bands averaged 35 for lakes (range 21-55), 35 for connecting streams (15-58), and 30 for lake-less streams (11-52) with an overall average of 34. Similar numbers of bands were found in an earlier study of Toolik Lake (Crump et al. 2003), and were also found in a temperate river, an estuary, and the Gulf of Maine (Crump et al. 2004); these comparisons are conservative because they use the same DGGE technique, primers, PCR conditions, and band selection criteria. In lakes, number of DGGE bands was uncorrelated with environmental measures on individual sampling dates except in July 2002 when band number and conductivity were related (Spearman's rank corre- lation, $P=0.015)$. In streams, number of DGGE bands correlated with temperature in July $2000(P<0.001)$ and July $2002(P=0.03)$. Across lakes and streams together, number of DGGE bands correlated positively with temperature $(P<0.02)$ in July 2000, August 2001, and August 2002, and negatively with temperature in July 2001. Band number also correlated negatively with conductivity $(P<0.02)$ in August 2001 and 2002. These relationships were driven by colder temperatures, higher conductivity, and fewer DGGE bands (except July 2001 when there were more) in lake-less streams. Also, pairwise differences in number of DGGE bands calculated on each sampling date were unrelated to pairwise DGGE similarity values or to pairwise differences in environmental factors.

Bacterial community composition varied across lakes and streams during each sampling campaign. Lake communities tended to be very similar to one another (average similarity 0.73 ; i.e., $73 \%$ similar, Fig. 2A). Communities in connecting streams, sampled at lake inlets, were similar to communities in lakes (average similarity 0.67 for all pairwise comparisons). In contrast, lake-less stream communities were almost always very different than lake communities (average similarity 0.30 for all pairwise comparisons). Similarity values among lake-less stream communities were low except between the hydraulically connected I-8 headwaters and I-8 inlet (same stream, two different sampling points had average similarity of $0.66, n=4)$. MDS ordinations of DGGE 

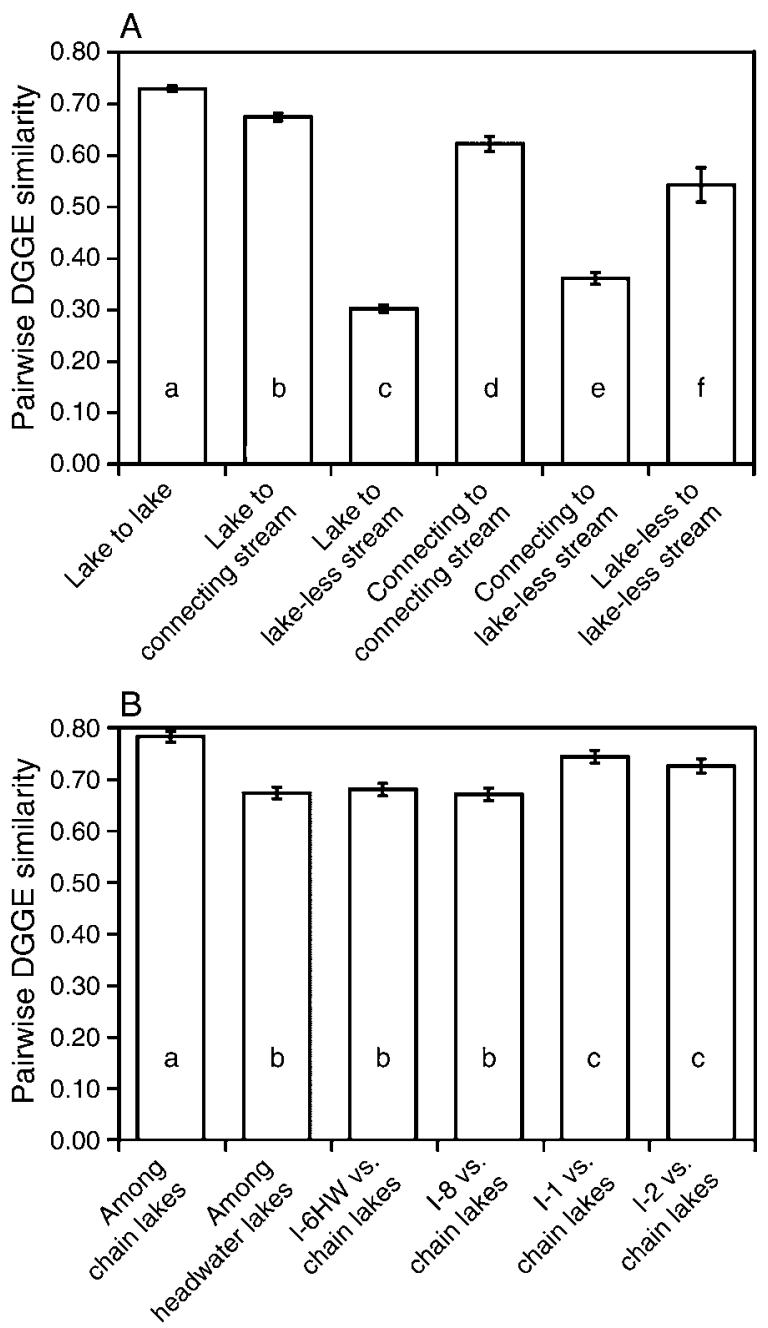

FIG. 2. (A) Pairwise similarity values (mean \pm SE) for DGGE (denaturing gradient gel electrophoresis) banding patterns among lakes, connecting streams, and lake-less streams. Wilcoxon Mann-Whitney tests indicate that mean values are all significantly different than one another $(P<$ 0.005 ; except between e and $\mathrm{f}$, where $P<0.05$ ). Number of comparisons are: lake to lake, 306; lake to connecting stream, 451; lake to lake-less stream, 189; connecting to connecting stream, 141; connecting to lake-less stream, 117; lake-less to lake-less stream, 20. (B) Pairwise similarity values (mean $\pm \mathrm{SE}$ ) for DGGE banding patterns among the chain of connected lakes in the western catchment (I-3, I-4, I-5, I-6, I-7, I-swamp), among the four headwater lakes (I-1, I-2, I-6HW, I-8), and between each headwater lake and the chain of connected lakes. Wilcoxon Mann-Whitney tests grouped pairwise similarity values into three categories $(P<0.01)$. Number of comparisons are: among chain lakes, 105; among headwater lakes, 39; I$6 \mathrm{HW}$ vs. chain lakes, 36 ; I-8 vs. chain lakes, 42 ; I-1 vs. chain lakes, 42; I-2 vs. chain lakes, 42.

similarity values reflected these patterns of bacterial community composition across the landscape on each sampling date, as exemplified in Fig. 3A which shows results from August 2002. These figures show that lake communities were closely related to connecting stream communities, with the exception of stream I-6HW to I-6, and that lake-less stream communities were more variable.

CCA analysis of lakes and streams on each sampling date indicated that variability in bacterial community composition across the landscape was best described by a combination of environmental and geographic factors. Models explaining 13-40\% of this variability included temperature and elevation on most dates, but also included conductivity, DOC, and $\mathrm{pH}$ on some dates (Table 2). CCA on lakes alone indicated that bacterial community composition was best described by geographic factors (elevation, lake hydrology), and, on some dates, by environmental factors (conductivity, temperature, $\mathrm{pH}$; Table 2). When significant, these
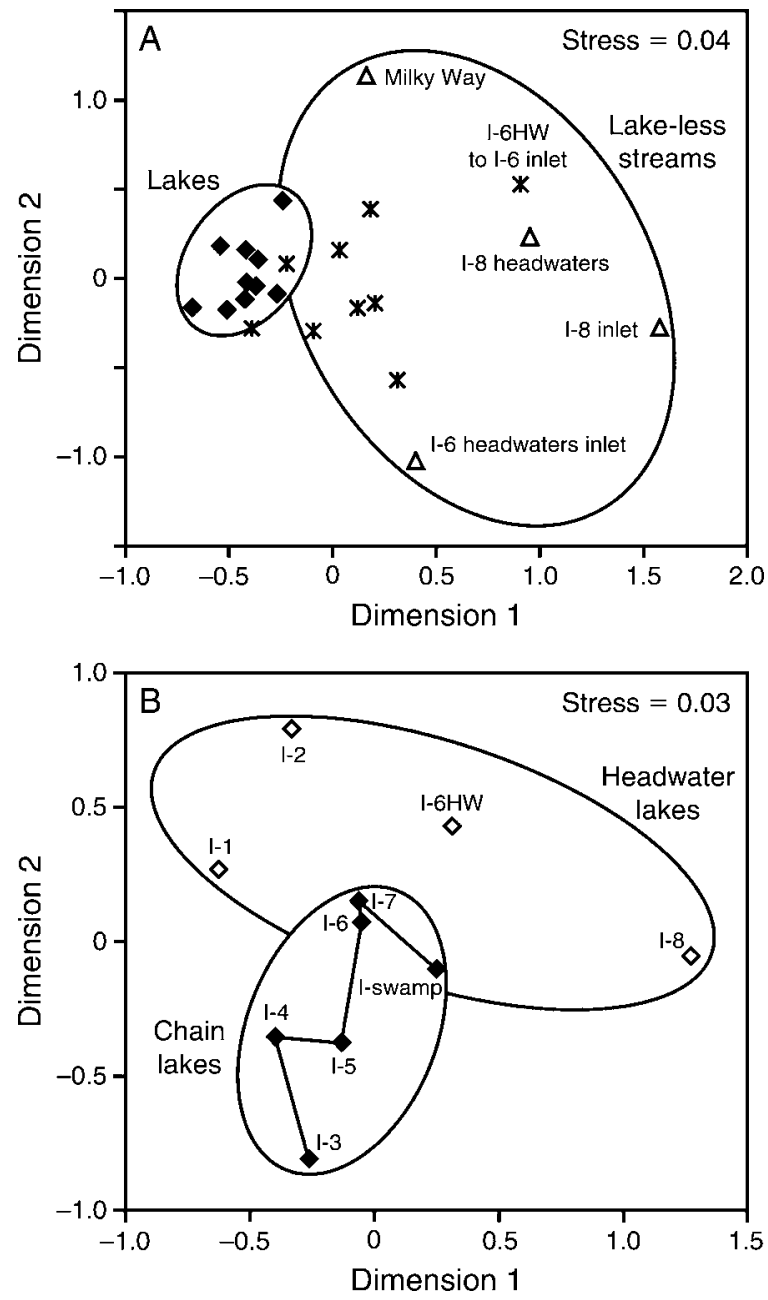

FIG. 3. Multidimensional scaling ordinations (with values of normalized stress) of pairwise estimates of similarity (Dice) calculated from DGGE banding patterns of DNA samples collected 6-7 August 2002. (A) Comparisons among all samples. Symbols indicate lakes (solid diamonds), connecting streams (stars [X]), and lake-less streams (open triangles). (B) Comparisons among lakes only. Symbols indicate flow-through chain lakes (solid diamonds) and headwater lakes (open diamonds). Chain lakes are connected with a line. 
models explained $16-68 \%$ of variability in bacterial community composition among lakes.

Connecting streams often contained bacterial communities that were very similar to those in their source lake, but the degree of similarity varied with stream and with sampling date. When all connecting streams were analyzed, variability in the degree of bacterial community change was well described by changes in $\mathrm{K}^{+}$ concentration (from lake outlet down the stream reach), stream length (measured from the nearest upstream lake), and flow rate (Table 3). According to this model, bacterial communities changed more in longer streams in which $\mathrm{K}^{+}$decreased, and also changed more on days that the streams were flowing slowly (Table 3). Omitting the results from August 2002, when stream flow was extremely low, improved the model slightly, and the important factors in the model changed. We found, however, that these relationships were strongly driven by changes in the very long stream I-6HW to I-6. When this stream was removed from the analysis, changes in bacterial community composition were best described by variability in $\mathrm{CO}_{2}$, drainage area, and temperature. In these models, communities changed more in streams that experienced large increases in $\mathrm{CO}_{2}$ along the reach. These results are consistent with the fact that streams leaving lakes lose their "lake-like" characteristics as a function of downstream distance (e.g., Kling et al. 2000). Overall, these correlations of communities and environmental factors in streams indicate that inputs of bacteria from land may be important.

MDS ordinations of lakes only, exemplified in Fig. 3B for August 2002, suggested that lakes in the central chain (I-3 to I-swamp) shared a similar bacterial community that was different than those in unconnected Lake I-8, distantly connected Lake I-6HW, and in some cases headwater Lakes I-1 and I-2. We tested the significance of this by comparing pairwise similarity values among the chain of connected lakes (I-3 through I-swamp) with pairwise similarity values between the chain lakes and Lakes I-6HW, I-8, I-1 and I-2. Similarity among chain lakes $(0.78)$ was significantly higher than between chain lakes and these other lakes (average of 0.67 for I-6HW and I-8, and 0.73 for I-1 and I-2), suggesting that closely connected lakes share similar bacterioplankton communities (Fig. 2B).

Environmental variables only weakly described variability in community composition among all lake-tolake comparisons (Table 3). However, when headwater lakes (I-1, I-2, I-6HW and I-8) and chain lakes (I-3, I-4, I-5, I-6, I-7, I-swamp) were considered separately, the geographic distance between the lakes explained a significant fraction of the variability in DGGE similarity values such that more distant lakes contained less similar communities (Fig. 4). Similarly, when sampling campaigns were analyzed individually, environmental variables only weakly described variability in lake-to-lake community similarity (Table 3 ). Distances between lakes or differences in elevation improved the regression models and were significant factors for five of seven sampling dates.

Patterns of relatedness among the connected chain of lakes and streams were investigated by averaging pairwise DGGE similarity values between lakes and up-slope environments. Each lake in the chain was compared to the first upstream lake, then to the second upstream lake, and so forth regardless of the starting position of the lake within the chain (Fig. 5). In addition, each lake was compared to its inlet stream (first upstream inlet), to the second inlet stream above the lake, and so forth. This analysis shows a trend of decreasing relatedness among lakes that are more distant in the chain, and a similar pattern among lakes and up-slope streams.

\section{Discussion}

It is clear from our results and other recent studies that microbial communities show non-random patterns in beta diversity (increasing spatial heterogeneity of diversity), and thus have biogeography (Papke et al. 2003, Whitaker et al. 2003, Horner-Devine et al. 2004). For aquatic bacteria, one study identified a relationship between distance and diversity patterns (Reche et al. 2005), one suggested the potential importance of dispersal via water flow within catchments (Lindström and Bergström 2005), one found no relationship between diversity and distance or dispersal (Konopka et al. 1999), and another found that both distance and environment were correlated with observed patterns of diversity (Yannarell and Triplett 2005). Despite this range of findings on the importance of environment or geographic separation, few if any studies have identified or tested the specific mechanisms leading to these patterns. Here, we discuss these mechanisms, and show that environmental characteristics and inoculation by dispersal are important in determining lake communities, and that "mass effects" through advection are important in stream communities.

A recent review of microbial biogeography (Martiny et al. 2006) compares the potential effects of dispersal and other "historical" controls with the influence of "contemporary environmental variation," and concludes that at smaller scales dispersal forces may be so far-reaching as to exclude biogeographic provinces. However, it remains a challenge to determine whether dispersal affects the composition of bacterial communities over and above the influence of environmental conditions. This is because accounting for all potentially important environmental factors is difficult, but also because many environmental factors co-vary with dispersal. For example, when rainstorms increase the rate of dispersal of microbes from riparian soil waters into a stream, they also alter stream chemistry by flushing organic materials from soils. In addition, the degree to which different environments and their microbial communities interact depends on geography and downslope water flow, and may also depend on other mechanisms such as aerosol 

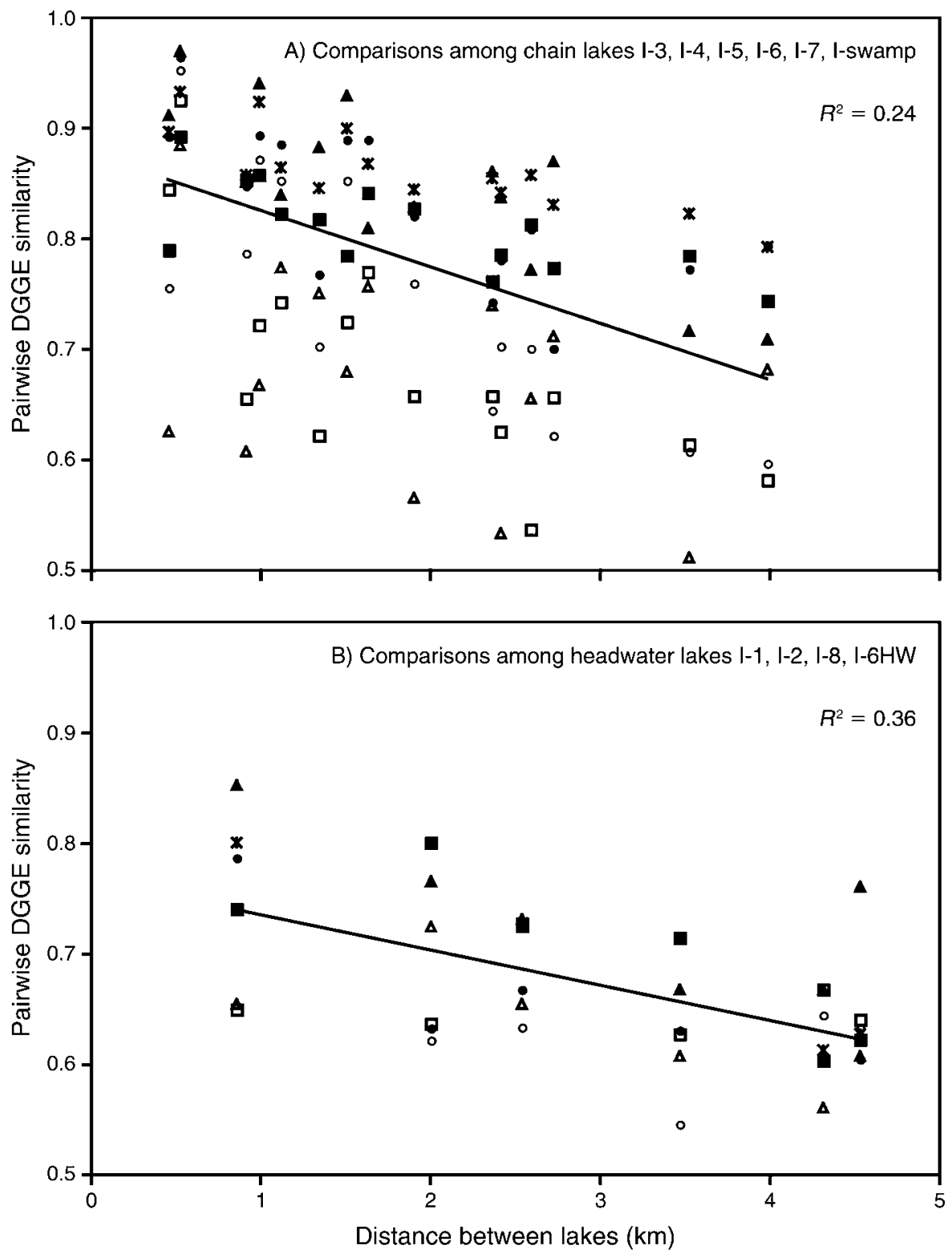

FIG. 4. Biplots of distance between lakes vs. pairwise similarity values of bacterial community composition (A) among lakes in the central chain, and (B) among headwater lakes. Symbols indicate the sampling dates: 6-7 July 2000 (stars [X]), 29-30 June 2001 (open circles), 17-18 July 2001 (open triangles), 7-8 August 2001 (solid circles), 25-26 June 2002 (open squares), 16-17 July 2002 (solid triangles), 6-7 August 2002 (solid squares).

transfers or animal movements. At one end of the spectrum, fast-flowing streams and lakes with short residence times should be dominated by organisms that wash in from up-slope environments regardless of whether these organisms can grow under local conditions; this is a "mass-effect perspective" in metacommunity theory (Leibold et al. 2004). For example, freshwater bacteria grow poorly at elevated salinity and yet are detected in estuaries simply because their immigration rate is higher than growth rates of resident organisms (Crump et al. 1999, 2004). In the present study, we observed this extreme form of mass-effect dispersal in streams where water residence time was very short relative to the community growth rate (Table 1).

At the other end of the spectrum, environments with long residence times should be dominated by welladapted communities of organisms. In these environments it matters greatly whether organisms dispersed from up-slope are able to grow under local conditions. Species that cannot grow, or those that grow slowly, will be diluted out, and thus reduce the similarity in community composition with up-slope or contributing environments. This situation is a "species sorting perspective" in which environmental conditions deter- 
mine community composition, and dispersal sets the metacommunity from which the dominant assemblage develops (Holyoak et al. 2005). Thus, there are two mechanisms by which dispersal can homogenize communities across a landscape: (1) advective transport of organisms in environments with short residence times, and (2) successful growth of organisms as they pass between systems with long residence times via downslope water flow or some other form of dispersal.

\section{Stream communities and processes}

Streams in the study catchments have short waterresidence times (Table 1) and thus are likely to be influenced by advection from up-slope environments. Our results demonstrate this mass-effect on stream communities through advective dispersal of lake bacteria, and also by providing evidence that terrestrial bacteria contribute to the mixture of organisms in streams.

Lake-less streams contained bacterial communities that were variable across the landscape and very different from communities in lakes. Community similarity between unconnected, lake-less streams averaged 0.46 with a maximum of 0.62 (Fig. 2). In contrast, communities in the lake-less stream sites I-8 headwaters and I-8 inlet that are connected (same stream) were more similar, with values averaging 0.65 and reaching 0.84 . These two sampling sites are separated by $5.2 \mathrm{~km}$, which establishes the ability of water flow to partially homogenize microbial communities over at least this distance. A study of the Ipswich River (Massachusetts) demonstrated a similar degree of variability among unconnected primary stream communities (Levine and Crump 2002), and on a broader spatial scale the abundance of bacterioplankton taxa were shown to be variable among nine streams in the eastern Unites States (Olapade et al. 2005, 2006).

Most streams that flowed between lakes contained bacterioplankton communities that resembled source lake communities and were very different from those in lake-less streams. However, in some connecting streams these communities were quite different from those in source lakes (Fig. 2), providing further support for the idea that streams receive important inputs of bacteria in addition to those from lakes. Potential sources for these organisms include soil water bacteria, bacteria flushed from the hyporheic zone, and bacteria sloughed from stream benthic habitats. Although these source communities were not characterized in our study, we can show that these sources are potentially important. For example, the largest change in connecting stream communities occurred in the stream flowing from Lakes I-6HW to I-6, which was the longest connecting stream in our study $(1.9 \mathrm{~km})$. Community composition changed along the length of this stream by an average of $63 \%$ and by as much as $75 \%$. Regression analysis including this stream indicated that community change was greater in longer streams and greater on days when streams were flowing more slowly. Also, when the I-6HW to I6 stream

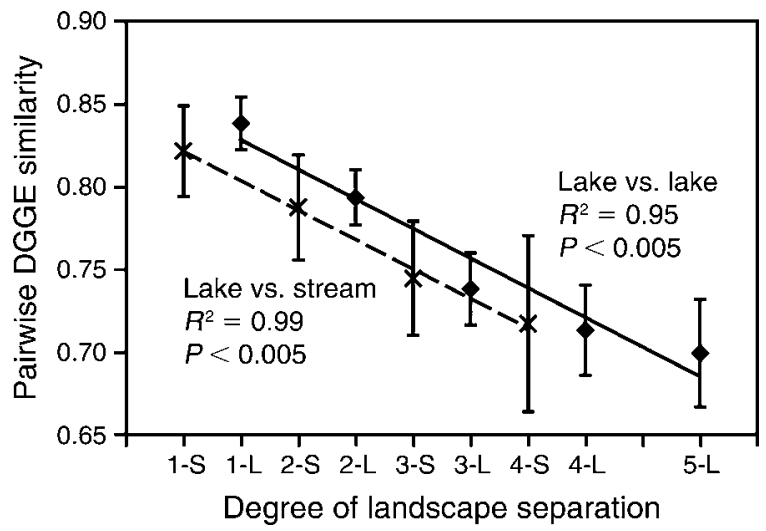

FIG. 5. Mean pairwise similarity values for DGGE banding patterns plotted against the degree of landscape separation. This separation is a categorical variable representing the number of upstream lakes or inlets separating two sites; $x$-axis values of 1-L mean that comparisons are made between a lake and its closest upstream lake, and 1-S compares a lake and its closest inlet stream; $x$-axis values of 2 represent a separation of two upstream lakes or two lake inlets. Error bars indicate \pm SE of all possible combinations within a category.

was excluded from the analysis, the drainage area of streams became a significant factor such that communities changed more in streams with larger contributing areas of land. Because stream length, flow rate, and drainage area influence seepage amounts and contact times with stream benthic and hyporheic zones, it is likely that these zones are important sources of "nonlake" bacteria to streams.

Bacterioplankton community change in streams was also related to changes in water chemistry. Our results demonstrated that stream communities changed more when ions $\left(\mathrm{K}^{+}\right.$or $\left.\mathrm{Mg}^{2+}\right)$ decreased along the length of stream (Table 3). When the very long stream between I$6 \mathrm{HW}$ and I-6 was omitted, shifts in community composition in shorter connecting streams were best described by changes in the concentration of dissolved $\mathrm{CO}_{2}$ such that communities changed more when $\mathrm{CO}_{2}$ increased moving down the stream segment. Soil waters and hyporheic waters in this region tend to have lower conductivity than lake waters (G. Kling, unpublished data), and they have elevated $\mathrm{CO}_{2}$ concentrations (Kling et al. 1991, Edwardson et al. 2003). It is possible that these different chemical inputs to streams from soil waters create an environment where lake bacteria are less well adapted than are stream surface or soil bacteria, but these observations are also consistent with the idea that community change in streams is driven by dilution with bacteria from the terrestrial environment (Boissier et al. 1996). As stream length or water residence time increases, the simple dilution of stream communities by terrestrial bacteria probably becomes less important and in situ growth of inoculated populations dominates any changes in community composition. 


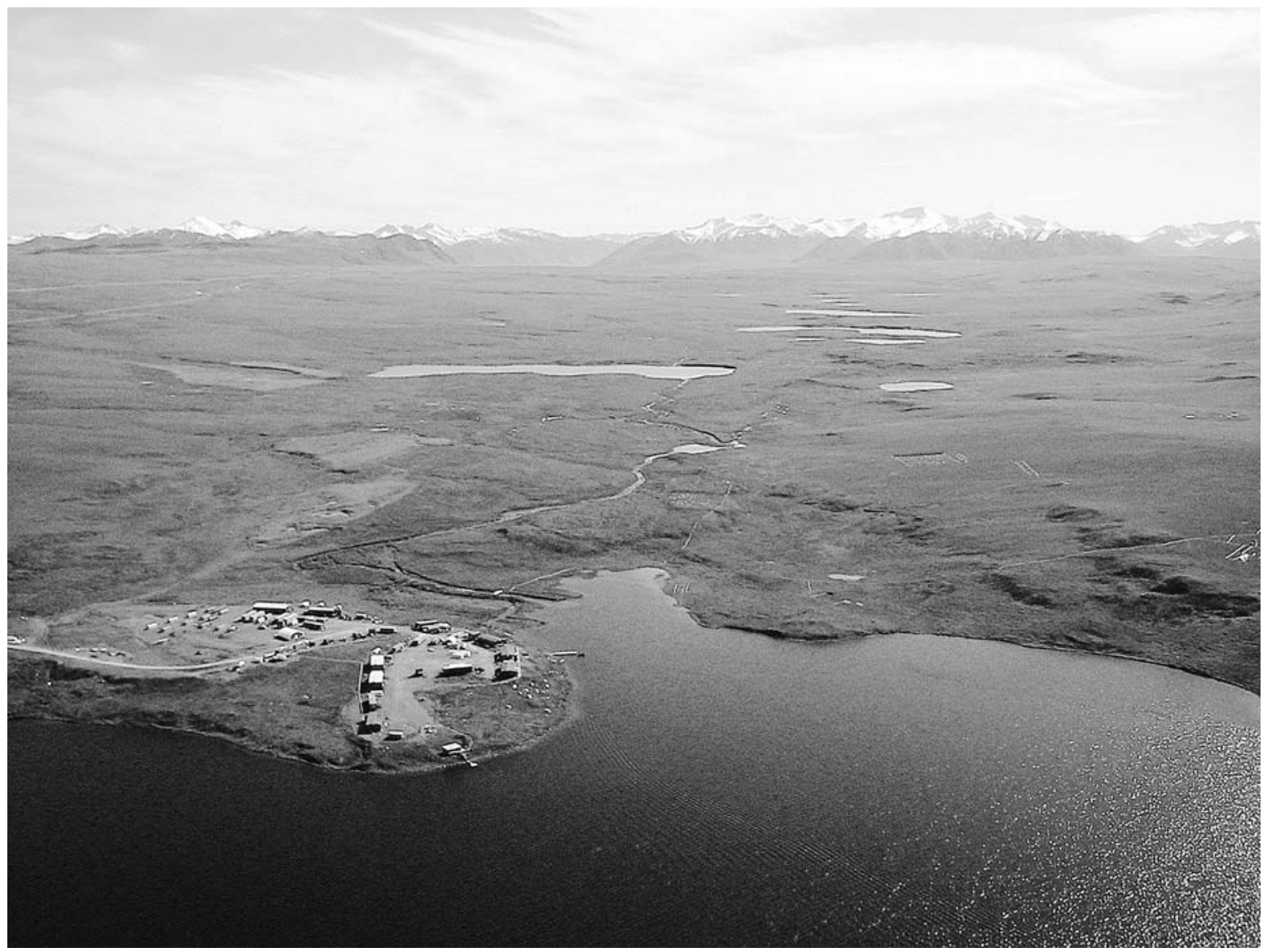

PLATE 1. Toolik Field Station on the south bank of Toolik Lake, Alaska, USA. View looking south across the Toolik Lake catchment toward the Brooks Mountain Range. Photo credit: @Institute of Arctic Biology; photo by Richard Flanders, used by permission.

\section{Lake communities and processes}

Lake bacterioplankton communities were much more similar across the landscape than stream communities (Fig. 2A), although several spatial patterns occurred repeatedly: (1) the hydraulically connected chain of lakes shared similar bacterioplankton communities (Fig. 2B); (2) the communities in these connected lakes shifted gradually and became less similar in lakes farther down catchment (Fig. 5); and (3) the unconnected Lake I-8 and the distantly connected Lake I-6HW contained communities more dissimilar to the connected lakes (Fig. 2B).

Epilimnetic residence times were much longer than bacterial community doubling times, indicating that unlike the situation in streams, bacteria advected from upstream sources constituted an insignificant fraction of the total number of cells in the lakes. In addition, epilimnion residence time was poorly related to the variation in community composition among lakes, and to the degree of similarity in communities between lakes and their inlet stream (data not shown). Long residence times and small stream inputs of cells mean that advected populations would have to grow greatly to be detected by DGGE. Such growth of allochthonous populations is likely in connected lakes because the streams carry many bacteria from the next upstream lake, and because the environmental conditions are similar among lakes. These effects of dispersal appear to be limited in their spatial extent, however, because despite long residence times the lake bacterial communities were most similar to communities in nearby lakes and particularly in nearby lakes connected by streams.

Although a long lake-water residence time (low stream water inputs) argues for lack of dispersal mass effects, there is a gradient of dispersal ranging from the advection of massive numbers of cells to the inoculation of small numbers of cells that may in turn grow to be important members of the community. For example, systems with shorter water residence times and comparable bacterial doubling times to ours often contain advected bacteria (Crump et al. 1999, 2004, Troussellier et al. 2002). And our study of connecting streams demonstrates that lake bacteria can be advected over large distances relative to the size of the lake. However, one study (Lindström and Bergström 2004) showed that 
TABLE 4. Number of DGGE bands that first appeared at each sampling station along the flow path from headwater Lakes I-1 and I-2 to Lake I-swamp, total numbers of unique bands that first appeared in lakes and streams, and the number of stream bands that persisted in lakes.

\begin{tabular}{|c|c|c|c|c|c|c|c|c|}
\hline \multirow[b]{2}{*}{ Lake/stream } & \multirow{2}{*}{$\frac{2000}{\text { July }}$} & \multicolumn{3}{|c|}{2001} & \multicolumn{3}{|c|}{2002} & \multirow[b]{2}{*}{ Mean } \\
\hline & & June & July & August & June & July & August & \\
\hline I-1 and I-2 & 48 & 39 & 35 & 34 & 50 & 62 & 46 & 45 \\
\hline $\mathrm{I}-1$ to $\mathrm{I}-3$ and $\mathrm{I}-2$ to $\mathrm{I}-3$ & 1 & 1 & 5 & 4 & 4 & 6 & 7 & 4 \\
\hline I-3 & 13 & 1 & 2 & 7 & 0 & 2 & 3 & 4 \\
\hline I-3 to I-4 & na $\dagger$ & na & na & na & na & na & na & na \\
\hline I-4 & 1 & 3 & 5 & 2 & 0 & 1 & 2 & 2 \\
\hline I-4 to I-5 & 0 & na & na & na & 0 & 0 & 8 & 2 \\
\hline $\mathrm{I}-5$ & 0 & 2 & 2 & 0 & 0 & 2 & 0 & 1 \\
\hline I-5 to I-6 & 0 & 1 & 5 & na & 7 & 5 & 0 & 3 \\
\hline $\mathrm{I}-6 \mathrm{HW}$ to I-6\$ & 13 & 16 & 9 & 12 & 15 & 18 & 6 & 13 \\
\hline I-6 & 0 & 1 & 2 & 1 & 0 & 1 & 1 & 1 \\
\hline I-6 to I-7 & 0 & na & na & na & na & na & na & 0 \\
\hline $\mathrm{I}-7$ & 0 & 1 & 1 & 0 & 1 & 1 & 0 & 1 \\
\hline I-7 to I-swamp & 0 & na & na & na & 1 & 0 & 1 & 1 \\
\hline I-swamp & 0 & 2 & 2 & 0 & 1 & 2 & 0 & 1 \\
\hline Total & 76 & 67 & 68 & 60 & 79 & 100 & 74 & 78 \\
\hline Lake bands & 62 & 49 & 49 & 44 & 52 & 71 & 52 & 54 \\
\hline Stream bands & 14 & 18 & 19 & 16 & 27 & 29 & 22 & 21 \\
\hline Stream bands that persist in lakes & 2 & 1 & 3 & 2 & 13 & 6 & 5 & 5 \\
\hline Stream bands not found in lakes & 12 & 17 & 16 & 14 & 14 & 23 & 17 & 16 \\
\hline
\end{tabular}

Note: na, not available.

$\dagger$ Not sampled.

\$ Stream I-6HW to I-6 enters the chain of lakes at Lake I-6.

a bacterioplankton community in a lake with a four month epilimnetic residence time resembled the community in its inlet stream. They estimated that the inlet stream supplied $0.03-0.4 \%$ of the bacterial cells in the epilimnion. The fact that this level is at or below the detection limit for PCR-based community fingerprinting methods argues against a strong mass-effect influence and for a weaker inoculation effect where some of the advected populations must grow to detectable size. These authors also studied a second lake with a 10-year residence time and found much lower similarity between inlet stream and lake communities. Thus, this lake falls even further down the gradient of mass effects, away from where advected cells dominate in number and toward weak inoculation where growth of introduced populations determines the similarity between adjoining landscape patches or habitats.

We observed patterns in environmental variation that were correlated with spatial patterns in bacterioplankton community composition. The clearest pattern of environmental variation was in conductivity, with lowest values in the upper chain lakes (including I-1 and I-2), higher values in the lower chain lakes, and maximum values in I-8 and I-6HW (pattern also found by Kling et al. [2000]). Community composition shifted together with conductivity moving downslope in the chain of lakes, and both were significantly different than those in Lakes I-8 and I-6HW. For individual sampling dates, conductivity contributed significantly to CCA and multiple regression models for samples from July 2000 and 2002, and August 2001 (Tables 2 and 3). Across all sampling dates, conductivity and other environmental variables were significant in regression models, but only when I-8 and I-6HW were included in the analyses (Table 3). These results suggest that conductivity or some co-varying environmental factor influences the composition of lake bacterioplankton communities.

The roles of dispersal and environment can be better understood by studying the patterns of community change across space. For example, environmental conditions were often subordinate to geographic distance or difference in elevation in predicting variability in bacterial community composition (Tables 2 and 3). In our study, $83 \%$ of the unique DGGE bands (populations) detected in the chain of connected lakes appeared in the headwater lakes I-1 and I-2 (Table 4). These bands continued to be a significant fraction of the bands in all downstream lakes, suggesting that dispersal of these communities influences downstream diversity. In addition to this inoculation from the headwater lakes' metacommunity, new populations also appeared in downstream lakes and replaced some existing populations. The appearance of these populations indicates that the character of inoculation changes moving downslope due to the contributions of new habitats or metacommunities, such as soil waters or stream beds. In many cases these new populations persisted in lakes farther downslope, which caused the communities in adjacent lakes to be more similar than communities in more distant lakes in the chain (Fig. 5). However, if inoculation and dispersal were the only important factors, then downstream lakes would contain an accumulation of all upstream lake populations in the chain. This was not observed (Table 4), and thus demonstrates that the documented environmental variation is sufficient to render some patches (lakes) 
unsuitable for certain populations. Our data suggest that even over restricted spatial scales $(<10 \mathrm{~km})$ variable inoculation and dispersal play a role in establishing the metacommunities from which lake bacterial communities develop, while contemporary environmental conditions, including those predicted by metrics of landscape position, further control the composition of communities in our lakes.

\section{Lake-stream interactions}

It is clear that lakes and streams host different microbial communities, and that these two environment types and their microflora interact across the landscape. On average, more than a quarter of the total DGGE bands first appeared in connecting streams, suggesting that they originated from the stream bottom or from soil or hyporheic water (Table 4). We also found that a substantial fraction of these stream populations persisted in lakes; on average 10 new populations appeared in lakes below I-1 and I-2, and of those persistent populations 5 of them $(50 \%)$ came from streams (Table 4). The sources of the remaining new populations in lakes are unknown, but may include seepage flow and transfers from the littoral zone or upward mixing from deep-water communities in lakes with persistent hypolimnia. The persistence of stream populations in lakes, despite long hydraulic residence times, indicates that terrestrial inputs influence lake bacterial communities not only by modifying the chemical conditions of lakes, but also by introducing organisms that thrive under those conditions. These and other potential interactions between lakes, streams, and other aquatic environments indicate that understanding the mechanisms controlling microbial biogeography requires knowledge of the linkages among environments on heterogeneous landscapes.

\section{ACKNOWLEDGMENTS}

We thank A. Balser and L. Rogan for map preparation and geographic information, and A. Anstead, M. Bahr, L. Barske, N. Bettez, M. Booth, M. Brahce, C. Crockett, M. Evans, A. Field, A. Floyd, C. Johnson, K. Judd, K. Keller, K. Lavigne, K. Riseng, D. Scanlon, and C. Wallace for assistance in the field and lab. This research was supported in part by the University of Michigan and University of Maryland, and by National Science Foundation grants OPP-0408371, OPP-9911681, OPP9911278, DEB-0423385, DEB-9810222, and ATM-0423385.

\section{Literature Cited}

Baas-Becking, L. G. M. 1934. Geobiologie of Inleiding Tot de Milieukunde. Van Stockum and Zoon, The Hague, The Netherlands.

Bergström, A. K., and M. Jansson. 2000. Bacterioplankton production in humic Lake Örträsket in relation to input of bacterial cells and input of allochthonous organic carbon. Microbial Ecology 39:101-115.

Boissier, J. M., P. Marmonier, C. Claret, D. Fontvieille, and P. Blanc. 1996. Comparison of solutes, nutrients, and bacteria inputs from two types of groundwater to the Rhone river during an artificial drought. Hydrobiologia 319:65-72.

Crump, B. C., E. V. Armbrust, and J. A. Baross. 1999. Phylogenetic analysis of particle-attached and free-living bacterial communities in the Columbia River, its estuary, and the adjacent coastal ocean. Applied and Environmental Microbiology 65:3192-3204.

Crump, B. C., and J. E. Hobbie. 2005. Synchrony and seasonality of bacterioplankton communities in two temperate rivers. Limnology and Oceanography 50:1718-1729.

Crump, B. C., C. S. Hopkinson, M. L. Sogin, and J. E. Hobbie. 2004. Microbial biogeography along an estuarine salinity gradient: combined influences of bacterial growth and residence time. Applied and Environmental Microbiology 70:1494-1505.

Crump, B. C., G. W. Kling, M. Bahr, and J. E. Hobbie. 2003. Bacterioplankton community shifts in an arctic lake correlate with seasonal changes in organic matter source. Applied and Environmental Microbiology 69:2253-2268.

Curtis, T. P., and W. T. Sloan. 2004. Prokaryotic diversity and its limits: microbial community structure in nature and implications for microbial ecology. Current Opinion in Microbiology 7:221-226.

Dolan, J. R. 2005. An introduction to the biogeography of aquatic microbes. Aquatic Microbial Ecology 41:39-48.

Edwardson, K. J., W. B. Bowden, C. Dahm, and J. Morrice. 2003. The hydraulic characteristics and geochemistry of hyporheic and parafluvial zones in Arctic tundra streams, north slope, Alaska. Advances in Water Resources 26:907923.

Fenchel, T. 2003. Biogeography for bacteria. Science 301:925926.

Findlay, S. E. G., R. L. Sinsabaugh, W. V. Sobczak, and M. Hoostal. 2003. Metabolic and structural response of hyporheic microbial communities to variations in supply of dissolved organic matter. Limnology and Oceanography 48: $1608-1617$.

Finlay, B. J. 2002. Global dispersal of free-living microbial eukaryote species. Science 296:1061-1063.

Hanski, I., and M. Gilpin. 1991. Metapopulation dynamicsbrief history and conceptual domain. Biological Journal of the Linnaean Society 42:3-16.

Hobbie, J. E., T. L. Corliss, and B. J. Peterson. 1983. Seasonal patterns of bacterial abundance in an arctic lake. Arctic and Alpine Research 15:253-259.

Hollibaugh, J. T., N. Bano, and H. W. Ducklow. 2002. Widespread distribution in polar oceans of a 16S rRNA gene sequence with affinity to Nitrosospira-like ammonia-oxidizing bacteria. Applied and Environmental Microbiology 68: 1478-1484.

Holyoak, M., M. A. Leibold, and R. D. Holt. 2005. Metacommunities. University of Chicago Press, Chicago, Illinois, USA.

Horner-Devine, M. C., M. Lage, J. B. Hughes, and B. J. M. Bohannan. 2004. A taxa-area relationship for bacteria. Nature 432:750-753.

Judd, K. E. 2004. Dissolved organic matter dynamics in an arctic tundra catchment: linking DOM chemistry, bioavailability, and microbial community composition. Dissertation. University of Michigan, Ann Arbor, Michigan, USA.

Judd, K. E., B. C. Crump, and G. W. Kling. 2006. Variation in dissolved organic matter controls bacterial production and community composition. Ecology 87:2068-2079.

Kirchman, D. L. 1993. Leucine incorporation as a measure of biomass production by heterotrophic bacteria. Pages 509-512 in P. F. Kemp, B. F. Sherr, E. B. Sherr, and J. J. Cole, editors. Handbook of methods in aquatic microbial ecology. Lewis Publishers, Boca Raton, Florida, USA.

Kirchman, D. L. 2002. Calculating microbial growth rates from data on production and standing stocks. Marine EcologyProgress Series 233:303-306.

Kling, G. W., G. W. Kipphut, and M. C. Miller. 1991. Arctic lakes and streams as gas conduits to the atmosphere: implications for tundra carbon budgets. Science 251:298-301. 
Kling, G. W., G. W. Kipphut, M. C. Miller, and W. J. O'Brien. 2000. Integration of lakes and streams in a landscape perspective: the importance of material processing on spatial patterns and temporal coherence. Freshwater Biology 43: 477-497.

Konopka, A., T. Bercot, and C. Nakatsu. 1999. Bacterioplankton community diversity in a series of thermally stratified lakes. Microbial Ecology 38:126-135.

Lee, S., and J. A. Fuhrman. 1987. Relationships between biovolume and biomass of naturally derived marine bacterioplankton. Applied and Environmental Microbiology 53: 1298-1303.

Leibold, M. A., M. Holyoak, N. Mouquet, P. Amarasekare, J. M. Chase, M. F. Hoopes, R. D. Holt, J. B. Shurin, R. Law, D. Tilman, M. Loreau, and A. Gonzalez. 2004. The metacommunity concept: a framework for multi-scale community ecology. Ecology Letters 7:601-613.

Levine, U. Y., and B. C. Crump. 2002. Bacterioplankton community composition in flowing waters of the Ipswich River watershed. Biological Bulletin 203:251-252.

Levins, R. 1969. Effect of random variations of different types on population growth. Proceedings of the National Academy of Sciences (USA) 62:1061-1065.

Lindström, E. S., and A. K. Bergström. 2004. Influence of inlet bacteria on bacterioplankton assemblage composition in lakes of different hydraulic retention time. Limnology and Oceanography 49:125-136.

Lindström, E. S., and A. K. Bergström. 2005. Community composition of bacterioplankton and cell transport in lakes in two different drainage areas. Aquatic Sciences 67:210-219.

Lindström, E. S., M. P. Kamst-Van Agterveld, and G. Zwart. 2005. Distribution of typical freshwater bacterial groups is associated with $\mathrm{pH}$, temperature, and lake water retention time. Applied and Environmental Microbiology 71:82018206.

Magnuson, J. J., B. J. Benson, and T. K. Kratz. 1990. Temporal coherence in the limnology of a suite of lakes in Wisconsin, USA. Freshwater Biology 23:145-159.

Martiny, J. B. H., et al. 2006. Microbial biogeography: putting microorganisms on the map. Nature Reviews Microbiology 4:102-112.

Muylaert, K., K. Van der Gucht, N. Vloemans, L. De Meester, M. Gillis, and W. Vyverman. 2002. Relationship between bacterial community composition and bottom-up versus topdown variables in four eutrophic shallow lakes. Applied and Environmental Microbiology 68:4740-4750.

Muyzer, G., E. C. Dewaal, and A. G. Uitterlinden. 1993. Profiling of complex microbial populations by denaturing gradient gel-electrophoresis analysis of polymerase chain reaction-amplified genes coding for 16s ribosomal-RNA. Applied and Environmental Microbiology 59:695-700.

Olapade, O. A., A. Brothers, M. Crissman, X. Q. Gao, and L. G. Leff. 2006. Comparison of planktonic microbial communities among nine North American streams. Archiv Fur Hydrobiologie 165:221-239.

Olapade, O. A., X. Gao, and L. G. Leff. 2005. Abundance of three bacterial populations in selected streams. Microbial Ecology 49:461-467.

Papke, R. T., N. B. Ramsing, M. M. Bateson, and D. M. Ward. 2003. Geographical isolation in hot spring cyanobacteria. Environmental Microbiology 5:650-659.

Reche, I., E. Pulido-Villena, R. Morales-Baquero, and E. O. Casamayor. 2005. Does ecosystem size determine aquatic bacterial richness? Ecology 86:1715-1722.

Riera, J. L., J. J. Magnuson, T. K. Kratz, and K. E. Webster. 2000. A geomorphic template for the analysis of lake districts applied to the Northern Highland Lake District, Wisconsin, USA. Freshwater Biology 43:301-318.

Simek, K., J. Nedoma, J. Pernthaler, T. Posch, and J. R. Dolan. 2002. Altering the balance between bacterial production and protistan bacterivory triggers shifts in freshwater bacterial community composition. Antonie Van Leeuwenhoek International Journal of General and Molecular Microbiology 81: 453-463.

Soranno, P. A., K. E. Webster, J. L. Riera, T. K. Kratz, J. S. Baron, P. A. Bukaveckas, G. W. Kling, D. S. White, N. Caine, R. C. Lathrop, and P. R. Leavitt. 1999. Spatial variation among lakes within landscapes: ecological organization along lake chains. Ecosystems 2:395-410.

Troussellier, M., H. Schafer, N. Batailler, L. Bernard, C. Courties, P. Lebaron, G. Muyzer, P. Servais, and J. VivesRego. 2002. Bacterial activity and genetic richness along an estuarine gradient (Rhone River plume, France). Aquatic Microbial Ecology 28:13-24.

Whitaker, R. J., D. W. Grogan, and J. W. Taylor. 2003. Geographic barriers isolate endemic populations of hyperthermophilic archaea. Science 301:976-978.

Yannarell, A. C., and E. W. Triplett. 2004. Within- and between-lake variability in the composition of bacterioplankton communities: investigations using multiple spatial scales. Applied and Environmental Microbiology 70:214-223.

Yannarell, A. C., and E. W. Triplett. 2005. Geographic and environmental sources of variation in lake bacterial community composition. Applied and Environmental Microbiology 71:227-239. 